\title{
Ontogeny of Atrial Natriuretic Peptide and Its Receptor In the Lung: Effects on Perinatal Surfactant Release
}

\author{
CHRISTOPHER A. D'ANGELIS, BRUCE A. HOLM, SATYAN LAKSHMINRUSIMHA, PETER A. NICKERSON, \\ DANIEL D. SWARTZ, JUNE SOKOLOWSKI, LORI C. NIELSEN, AND RITA M. RYAN
}

\author{
Departments of Pathology and Anatomical Sciences [C.A.D., P.A.N., R.M.R.], Pediatrics [B.A.H., S.L., D.D.S., J.S., L.C.N., R.M.R.], \\ Pharmacology [B.A.H.], and Gynecology-Obstetrics [R.M.R.], State University of New York at Buffalo School of Medicine and Biomedical \\ Sciences, Buffalo, New York 14214
}

\begin{abstract}
During the transition at birth to air breathing, regulation of surfactant release from alveolar type II (ATII) cells is critical. Atrial natriuretic peptide (ANP) stimulates natriuretic peptide receptor-A (NPR-A) and increases intracellular cGMP. We examined the changes in ANP and NPR-A in respiratory epithelium during the perinatal period using immunohistochemistry and studied the effect of ANP on surfactant release from ATII cells isolated from fetal and newborn lambs. NPR-A mRNA was detected in the fetal lung by Northern Blot and RT-PCR. At 100 d gestation (term 145 d), ANP staining was absent and NPR-A staining was weak in cuboidal epithelial cells. ANP and NPR-A staining was prominent in ATII cells at $136 \mathrm{~d}$ gestation and was undetectable postnatally. ANP stimulated (maximal effect at $10^{-10} \mathrm{M}$ ) surfactant release from both late gestation fetal and neonatal ATII cells. Protein kinase G inhibition significantly blocked this release. We conclude that ANP stimulates surfactant release in isolated perinatal ATII cells by a cGMPdependent mechanism. ANP and NPR-A expression in ATII cells is greatest in late gestation and declines sharply postnatally. We speculate that increased activity of the ANP/NPR-A pathway in late gestation may prime the surfactant system, preparing the lung for air breathing. (Pediatr Res 63: 239-244, 2008)
\end{abstract}

$\mathrm{T}^{1}$ hrough its production and release of surfactant into the alveolus, the alveolar type II cell (ATII) plays a critical role in the transition from placental to pulmonary respiration at birth. The release of surfactant by ATII cells is a highly coordinated process that is regulated by numerous circulating factors (1-3). Previous studies have demonstrated that the hormone atrial natriuretic peptide (ANP) is capable of modulating ATII cell function in the adult (4); however, its role in regulating surfactant release in the perinatal period is unknown. ANP is a member of the natriuretic peptide (NP) family. The natriuretic peptide receptor-A (NPR-A) is specific for ANP and is a member of the membrane guanylyl cyclase family (5). The physiologic responses seen following NPR-A activation are mediated by cGMP and the subsequent activation of the cGMP-dependent protein kinase $\mathrm{G}$ (PKG) cascade $(6,7)$.

Received May 1, 2007; accepted October 15, 2007.

Correspondence: Rita M. Ryan, M.D., Division of Neonatology, State University of New York at Buffalo, Women \& Children's Hospital of Buffalo, 219 Bryant Street, Buffalo, NY 14222; e-mail: rryan@upa.chob.edu

This work was supported, in part, by NIH grant HL56176 and the Department of Pediatrics, SUNY Buffalo.
The primary source of circulating ANP in the fetus are the cardiac atria $(8,9)$. Fetal plasma ANP increases sharply during late gestation (reaching levels 5-6 times that seen in adults) (10). ANP synthesis and binding have also been documented in other tissues including the brain $(11,12)$, systemic and pulmonary vasculature (13), and lung (14). Studies investigating the NP within the developing lung have been limited to its role within the pulmonary vasculature. In the perinatal period, the pulmonary vascular NP system is upregulated (15) and is believed to contribute to the establishment of a low-pulmonary vascular resistance necessary at birth (16). Although the developing lung synthesizes ANP and contains large numbers of ANP binding sites $(17,18)$, the specific pulmonary cell types responsible for this and the possible role of ANP in lung development remain largely unknown.

Currently, no study has examined comprehensively the expression of ANP and NPR-A in respiratory epithelial cells during fetal and neonatal lung development. Furthermore, ANP-specific effects on surfactant release from fetal and newborn ATII cells have not been investigated. Using antibodies specific to ANP and NPR-A, we sought to identify the sites of potential ANP expression within the developing respiratory epithelium and to determine the effect of birth on this expression. We have developed an in vitro assay utilizing primary cultures of sheep fetal and newborn ATII cells to examine the effect of stimulation of the ANP/NPR-A pathway upon surfactant release.

\section{MATERIALS AND METHODS}

Immunohistochemistry for ANP and NPR-A. All protocols were approved by the SUNY Buffalo Institutional Animal Care and Use Committee. Our immunohistochemistry protocol has been described in detail (16). Pregnant ewes were anesthetized by i.v. pentobarbital $(750 \mathrm{mg})$ followed by isoflurane $(1.5 \%)$ inhalation. Fetal lambs were delivered by C-section and killed at 100 and $136 \mathrm{~d}$ gestation (term $145 \mathrm{~d}$ ). Newborn ( $3 \mathrm{~d}$ after spontaneous term vaginal delivery) and 4-wk-old lambs were killed by an i.v. injection of $5 \mathrm{~mL}$ pentobarbital sodium (Fatal Plus, Vortech Pharmaceuticals, Dearborn, MI). The left lung was removed at the level of the mainstem bronchus and instilled with formalin for $24 \mathrm{~h}$. Lung and control tissue blocks were embedded in paraffin and immunostained for: ANP and prepro-ANP (rabbit anti-human: 1:2000 and 1:1500, overnight incubation at $4{ }^{\circ} \mathrm{C}$, Penin-

Abbreviations: ANP, atrial natriuretic peptide; ATII, alveolar type II cell; JMEM, Joklik's modified essential media; NP, natriuretic peptide; NPR-A, natriuretic peptide receptor A; PC, phosphatidyl choline; PET, Rp-8-Br-PETcGMPS; PKG, protein kinase G; SP-B, surfactant protein B; SIP, stock isosmotic percoll 
sula Labs, Belmont, CA), NPR-A (rabbit anti-rat NPR-A-1:1500, overnight incubation at room temperature, a generous gift of Dr. D. Garbers) $(19,20)$, or surfactant protein-B (SP-B) (rabbit anti-human SP-B-1:1200, overnight incubation at $4^{\circ} \mathrm{C}$, Chemicon, Temecula, CA). Antibody binding was visualized using SigmaFast DAB (3,3'-Diaminobenzidine Tetrahydrochloride and $\mathrm{H}_{2} \mathrm{O}_{2}$ ) followed by counterstaining with Mayer's hematoxylin (Sigma Chemical Co., St. Louis, MO).

RT-PCR and Northern blotting for NPR-A. Briefly, total lung RNA was reverse transcribed using Moloney Murine Leukemia Virus reverse transcriptase and subjected to PCR using the primers GCTCCTGCAGTCCCCAAATGTGGCTTTGACAA and GGGAATTCATTCTGCACATCCCGCATAT upstream and downstream, respectively, to generate a $440 \mathrm{bp}$ fragment which was subsequently sequenced and cloned into a pGEM -3Zf + vector (Promega, Madison WI). RT-PCR was conducted as described previously (16). The plasmid was linearized and $\mathrm{P}^{32}$ labeled antisense cRNA used to probe Northern blots of total cellular RNA to identify a predicted $4.4 \mathrm{~Kb}$ band (21).

Isolation of ATII cells from fetal and newborn lambs. The fetal chest cavity was exposed by a midline sternotomy. Heparin $400 \mathrm{U} / \mathrm{kg}$ was injected directly into the right ventricle and a heparinized cannula was inserted into the left ventricle, and blood was aspirated. The aortic arch and the inferior vena cava were clamped, the left atrial wall was opened, and warmed Hanks balanced salts solution (HBSS; Sigma Chemical Co.) was instilled into the pulmonary vasculature through the right ventricle. Flushing of the pulmonary vascular bed was considered complete when the outflow from the left atria was clear and lung blanching was apparent. The heart and lungs were removed and the right lung was separated leaving the entire left lung attached to the heart through the left main pulmonary artery. A catheter fitted with a stopcock was fed into the left main bronchus. The heart was removed and the outer surface of the left lung was rinsed with saline to remove any blood. Newborn lambs (3 d) were anticoagulated by an injection of heparin $(400$ $\mathrm{U} / \mathrm{kg}$ ) before being killed and subjected to a similar protocol as fetal lambs.

Isolated left lungs of fetal and newborn lambs were lavaged with saline. A barium sulfate solution $(15 \mathrm{mg} / 100 \mathrm{~mL}$ in normal saline, Sigma Chemical Co.) was infused and the lung was incubated for $15 \mathrm{~min}$ at $37^{\circ} \mathrm{C}$. The barium solution was aspirated and the lung was lavaged with saline and warm minimal essential medium Joklik modification with L-Glutamine (JMEM) [JMEM, (Sigma Chemical Co.), $\mathrm{NaHCO}_{3} 2 \mathrm{~g} / \mathrm{L}$, HEPES $2.4 \mathrm{~g} / \mathrm{L}, \mathrm{H}_{2} \mathrm{O}-1 \mathrm{~L}$; $\mathrm{pH}=7.6]$. The lung was instilled with a protease solution (DNAase type I 2 mg (Sigma Chemical Co.), Elastase $(5.1 \mathrm{u} / \mathrm{mgP}) 3 \mathrm{~mL}$ (Worthington Biochemical, Lakewood, NJ), JMEM $200 \mathrm{~mL} ; 37^{\circ} \mathrm{C}$ ) and incubated for $30-35$ min at $37^{\circ} \mathrm{C}$. During the incubation period, the lung was kept full by recirculating the protease solution at $5-10 \mathrm{~min}$ intervals. The protease incubation was stopped by the instillation of $100 \mathrm{~mL}$ of JMEM with $10 \mathrm{~mL}$ of fetal bovine serum (FBS). The pleural membrane was teased away and the digested lung parenchyma was scraped gently into petri dishes and minced. The minced lung suspension was then added to $100 \mathrm{~mL}$ of a protease inhibitor solution (DNAase type I $10 \mathrm{mg}$, JMEM $180 \mathrm{~mL}$, FBS $10 \mathrm{~mL}$ ) and stirred for $15-20 \mathrm{~min}$ and filtered through a series of gauze filters $(150,40,15 \mu \mathrm{m})$, collected into $50 \mathrm{~mL}$ conical tubes and spun at $1500 \mathrm{~g}$ for 6 min at $4{ }^{\circ} \mathrm{C}$ to pellet the cells. Supernatants were discarded and the cell pellets were resuspended in 1-2 $\mathrm{mL}$ of JMEM and the cell suspension was brought to a final volume of $40 \mathrm{~mL}$ and $5 \mathrm{~mL}$ aliquots were loaded slowly into each of eight 50 $\mathrm{mL}$ glass tubes containing $12 \mathrm{~mL}$ of Percoll 1.04 and $2 \mathrm{~mL}$ of Percoll 1.08, followed by centrifugation at $2250 \mathrm{~g}$ for $25 \mathrm{~min}$ at $4^{\circ} \mathrm{C}$. Percoll gradients were made as follows: Stock isosmotic Percoll (SIP) $(p=1.13)$ : Percoll $90 \mathrm{~mL}$ (Sigma Chemical Co.), HBSS (10×) 10 mL; Percoll 1.04: SIP 30 mL, JMEM 70 mL; Percoll 1.08: SIP 11 mL, JMEM 7 mL. Two milliliter of Percoll (1.08) was added to each of eight $50 \mathrm{~mL}$ glass tubes followed by $12 \mathrm{~mL}$ of Percoll (1.04). The cell band between the 1.04 and 1.08 layers was drawn into four conical tubes and brought up to a final volume of $40 \mathrm{~mL}$ with JMEM and spun at $1500 \mathrm{~g}$ for $6 \mathrm{~min}$ to pellet the cells. The supernatant was discarded and the cell pellet was dissolved in $1 \mathrm{~mL}$ of warm DMEM (GIBCO, Grand Island, $\mathrm{NY}$ ), $\mathrm{NaHCO}_{3} 3.7 \mathrm{mg} / \mathrm{L} ; \mathrm{pH}=7.4$. Cell counts and viability were obtained using trypan blue staining with a hemocytometer. The cell suspension was incubated at a density of $15-20 \times 10^{6} \mathrm{cell} / \mathrm{s} / \mathrm{dish} / 8 \mathrm{~mL}$ serum-free DMEM on Petri dishes coated with sheep $\operatorname{IgG}$ (adapted from Dobbs (22)) and placed in a $37^{\circ} \mathrm{C}, 5 \% \mathrm{CO}_{2}$ incubator for $60 \mathrm{~min}$. The cell suspension was panned gently $4-5$ times, aspirated into a $50 \mathrm{~mL}$ tube and spun at $1500 \mathrm{~g}$ for 6 min at $4^{\circ} \mathrm{C}$ to pellet the cells. The cell pellets were resuspended in $5 \mathrm{~mL}$ of DMEM and a second cell count and trypan exclusion assay was performed.

The purity of the ATII cell suspensions was determined by a modified Papanicolaou staining of cytospin preparations (23) of aliquots removed after differential centrifugation alone and in combination with panning on sheep $\mathrm{IgG}$ coated plates.

Measurement of surfactant secretion from primary cultures of ATII cells isolated from fetal and newborn lambs. Each assay was performed using primary cultures obtained from single individual fetal and newborn lambs.
Petri dishes were prepared for cell culture by coating with rat-tail collagen (Biomedical Technologies, Stoughton, MA) diluted 1:10 in glacial acetic acid and sterile water (1:1000); $200 \mu \mathrm{L}$ were added to six-well culture plates and were allowed to dry overnight. After the ATII cell isolation procedure, the cell pellet was resuspended in warm DMEM with antibiotic/antimycotic (Life Technologies): penicillin-G 10,000 units $/ \mathrm{mL}$, streptomycin 10,000 $\mu \mathrm{g} / \mathrm{mL}$, amphotericin-B $25 \mu \mathrm{g} / \mathrm{mL}$ (stock diluted 1:200 in culture media), and 10\% charcoal stripped FBS to a final concentration of $1.5 \times 10^{6}$ cells $/ \mathrm{mL}$. To assess surfactant release, $1 \mu \mathrm{ci}^{3}[\mathrm{H}]$ choline chloride/mL (Amersham, Arlington Heights, IL) was added to the cell suspension. Two milliliters of the cell suspension was added to each well of a six-well plate and incubated for 16-18 $\mathrm{h}$ in a $5 \% \mathrm{CO}_{2}$ incubator at $37^{\circ} \mathrm{C}$.

The presence of ATII cells following overnight culture was assessed by tannic acid staining of cells cultured on collagen coated chamber slides at a concentration of $1 \times 10^{6}$ cells $/$ well $/ \mathrm{mL}$ using a previously described method (24). The media was discarded and plates were washed twice with warm serum free DMEM. One milliliter of warm serum free DMEM was added to each well and the cells were returned to the incubator for $30 \mathrm{~min}$. Cells were removed from the incubator, the selected agents (see below) were added and the plates were returned to the incubator for $3 \mathrm{~h}$. The media was removed and centrifuged for $10 \mathrm{~min}$ at $1500 \mathrm{rpm}$ to remove any cells. The supernatant was then transferred to screw top tubes and $3 \mathrm{~mL}$ of chloroform/ethanol (1:2) was added, the tubes were vortexed and stored at $-30^{\circ} \mathrm{C}$ until extracted. Normal saline $(800 \mu \mathrm{L})$ was added to each well and the cell layers were scraped off and placed into screw top tubes. The wells were washed with $2 \mathrm{~mL}$ of methanol, and $1 \mathrm{~mL}$ of chloroform was added to the cell scrapings, vortexed and stored at $-30^{\circ} \mathrm{C}$ until extracted as previously described (25). Samples were removed from $-30^{\circ} \mathrm{C}$ and $1 \mathrm{~mL}$ of chloroform and $1 \mathrm{~mL}$ of water were added, vortexed, and mixed for $15 \mathrm{~min}$ followed by centrifugation at 2400 rpm for $15 \mathrm{~min}$. The lipid layer was drawn off and placed in glass scintillation vials. A second extraction was performed by adding $2 \mathrm{~mL}$ of chloroform to each tube followed by mixing for $15 \mathrm{~min}$ and centrifugation for $15 \mathrm{~min}$. The lipid layer was removed and combined with the first extraction. Extracted samples were dried completely under a stream of air, reconstituted in $1 \mathrm{~mL}$ of chloroform and mixed with $9 \mathrm{~mL}$ of scintillation fluid. Counts for ${ }^{3}[\mathrm{H}]$ were obtained as cpm using a Wallac 1409 liquid scintillation counter. Data were expressed as percent surfactant release using the following calculation: [cpm in the extracted media/cpm in the extracted media $+\mathrm{cpm}$ in the extracted cells] $\times 100$.

Compounds tested in the surfactant secretion assay included ANP (human, 1-28 Peptides International, Louisville, KY); Terbutaline Sulfate (Breathine), $10^{-5} \mathrm{M}$ (Novartis); Rp-8-Br-PET-cGMPS, a PKG inhibitor (PET), $10^{-5} \mathrm{M}$, (Calbiochem, San Diego, CA). The dosages of terbutaline, ANP, and PET chosen for our assays were based upon preliminary studies in our laboratory and are consistent with that of previously published reports $(4,26)$.

Surfactant secretion data were analyzed by one-way ANOVA followed by Bonferonni's post hoc test for multiple comparisons using STATA 7.0 software (College Station, TX).

\section{RESULTS}

NPR-A Northern Blot and RT-PCR in fetal lung. NPR-A mRNA was identified by Northern blotting at $4.4 \mathrm{~Kb}$ (21) (Fig. 1) in whole lung samples from fetal lambs at $136 \mathrm{~d}$ gestation. RT-PCR analysis for detection of NPR-A in $136 \mathrm{~d}$ gestation fetal lung yielded a $440 \mathrm{bp}$ band as predicted (Fig. 1).

Immunohistochemistry for prepro-ANP, ANP, and NPR-A in fetal and newborn lamb lung. In all tissues and at all age groups studied, staining was absent in sections incubated with normal rabbit serum used in place of the primary antibodies (Fig. 2A). At $100 \mathrm{~d}$ of gestation, staining for SP-B (suggesting the presence of mature ATII cells) was absent in all lung epithelial cells (not shown). By $136 \mathrm{~d}$ of gestation and at $3 \mathrm{~d}$ and 4 -wk postgestation, SP-B staining was present in ATII cells (Fig. $2 B-D$ ). In addition to ATII cells, SP-B staining was also seen in nonciliated cells of the lower airways (Clara cells, not shown). Sections of pulmonary artery, cardiac atria, and kidney from newborn lambs demonstrated positive staining for prepro-ANP whereas no staining was identified in sections of lamb cerebellum (Fig. $2 E-H$ ). 
A

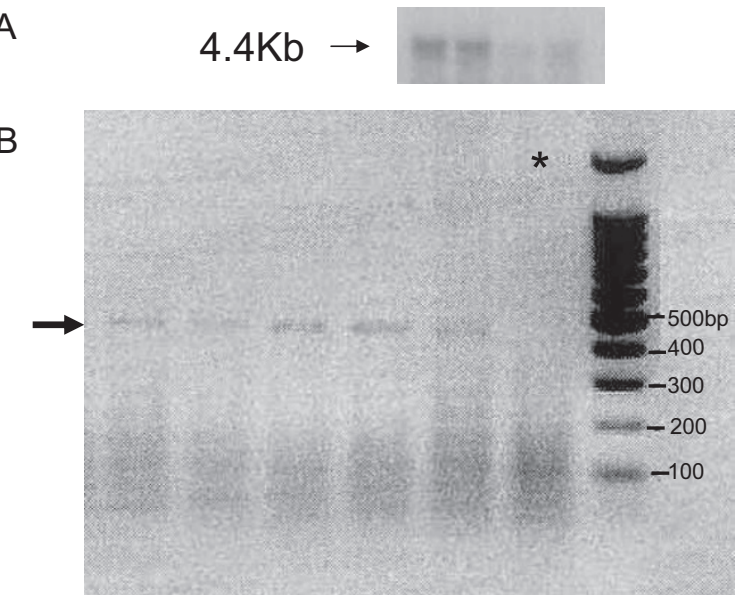

Figure 1. NPR-A mRNA was identified by Northern blotting at $4.4 \mathrm{~Kb}(A)$ and by RT-PCR at 440 bp ( $B$, arrow) in whole lung samples from fetal lambs at $136 \mathrm{~d}$ gestation. *Negative control is no reverse transcriptase.

At $100 \mathrm{~d}$ of gestation, staining for prepro-ANP and ANP was absent in all epithelial and vascular lung cells (Figs. $3 A$ and $4 A$ ). By $136 \mathrm{~d}$ of gestation, ATII cells and Clara cells demonstrated intense staining for both prepro-ANP and ANP (Figs. $3 B$ and $4 B$ ). At $3 \mathrm{~d}$ and 4 wk postnatal age, prepro-ANP, and ANP immunostaining was no longer detectable in ATII cells. Although prepro-ANP and ANP staining in Clara cells was still detectable after birth, the intensity of staining and number of positive cells was dramatically reduced when compared with the late term fetus (Figs. $3 C$ and $4 C$ ). Epithelial staining was decreased further by 4 wk of age (Figs. $3 D$ and $4 D$ ).

At $100 \mathrm{~d}$ of gestation, the cuboidal epithelial cells lining the developing distal airspaces were weakly positive for NPR-A (Fig. 5A). Positive NPR-A staining was clearly visible as a granular precipitate within the apical cytoplasmic surface of ATII cells from lambs at $136 \mathrm{~d}$ of gestation (Fig. $5 B$ ), but was absent in ATII cells from 3d and 4wk lambs (Fig. 5C,D). At $136 \mathrm{~d}$ of gestation, NPR-A expression was also seen in Clara cells lining the distal airways (Fig. 5B, inset). After birth, NPR-A staining in
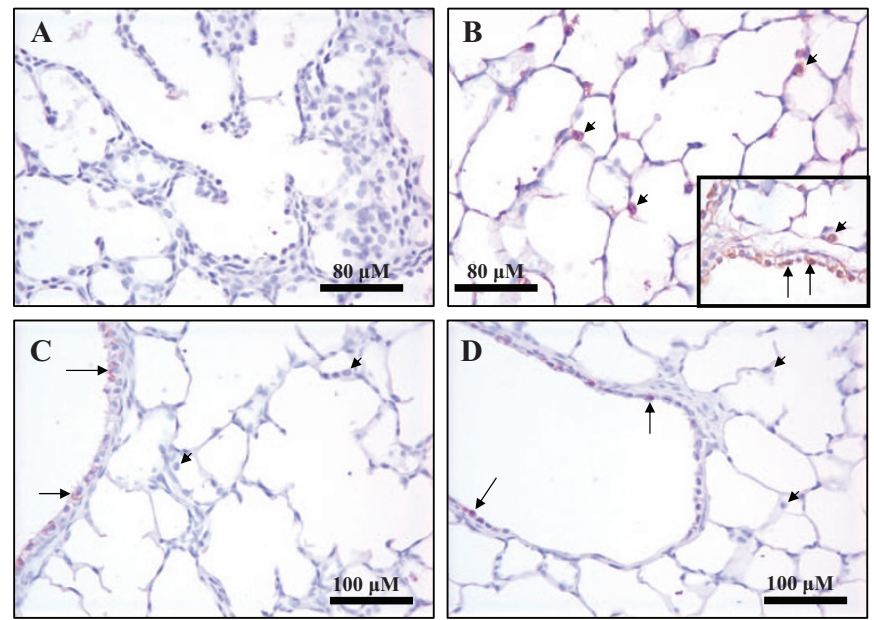

Figure 3. Prepro-ANP immunostaining in lamb lung. A, At $100 \mathrm{~d}$ gestation, prepro-ANP is absent from all lung cells. $B$, By $136 \mathrm{~d}$ of gestation, preproANP expression is present in ATII cells (arrowheads) and Clara cells (inset, arrows). $C$, Prepro-ANP is absent in ATII cells (arrowheads) but is still present within Clara cells (arrows) at $3 \mathrm{~d}$ post gestation. D, Prepro-ANP staining is further reduced in lung epithelium at $4 \mathrm{wk}$ of age.

Clara cells was reduced markedly but was still present in scattered cells of the distal airways even at $4 \mathrm{wk}$ of age (Fig. 5C, D). Within the larger conducting airways of $136 \mathrm{~d}$ fetal lambs, NPR-A was present along the membrane of ciliated columnar epithelium (Fig. 6B). Similar to that seen in the distal lung epithelium, NPR-A staining within the ciliated columnar epithelium of the bronchi also decreased dramatically after birth. In contrast, staining persisted within the adjacent nonepithelial structures such as chondrocytes and airway smooth muscle (Fig. $6 C, D)$.

Isolation and culture of alveolar type II cells from fetal and newborn lambs. The goal of our isolation protocol was to acquire an ATII cell preparation for use in primary culture with a purity of $>85 \%$, a cell number $>25 \times 10^{6}$ and cell viability $>90 \%$ as reported in other species (23). Two distinct methods for ATII cell isolation were tested both alone and in combination. The first isolation method, based upon differen-
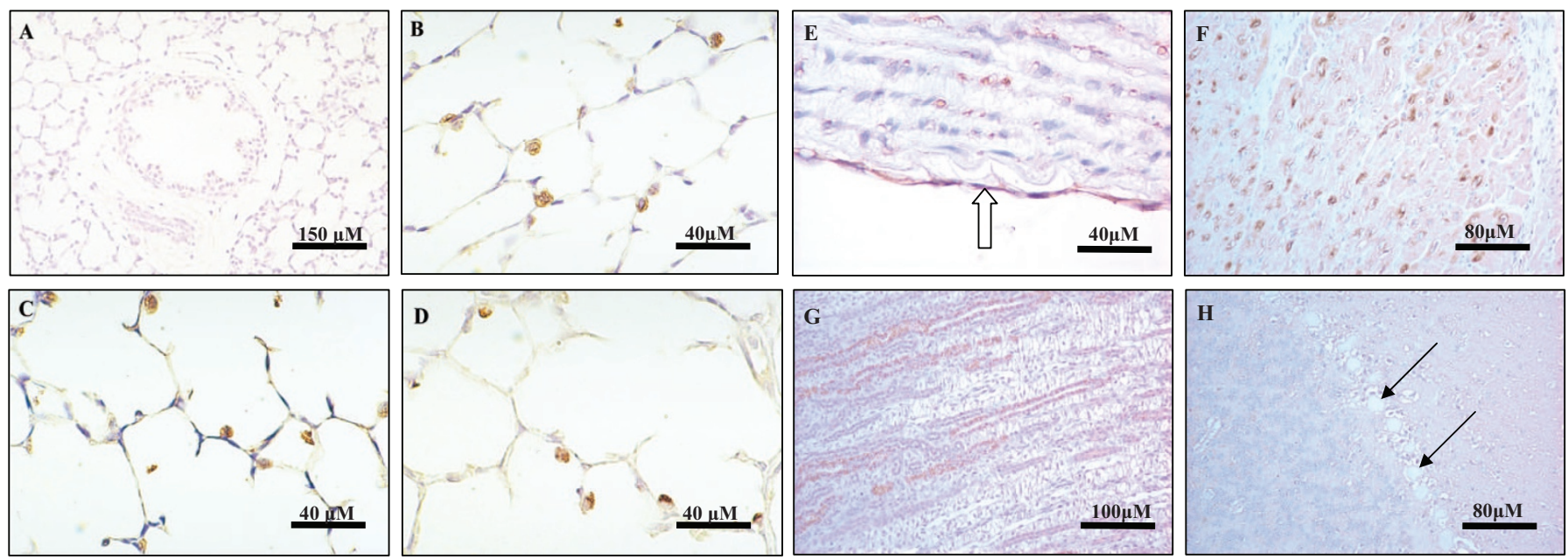

H

Figure 2. Controls for immunohistochemistry. $A, 136 \mathrm{~d}$ fetal lamb lung incubated with nonimmune rabbit serum in place of the primary antibodies. $B-D$, SP-B Staining in ATII cells at $136 \mathrm{~d}, 3 \mathrm{~d}$, and $4 \mathrm{wk} . E-H, 3 \mathrm{~d}$ lamb pulmonary vascular endothelium (open-arrow), cardiac myocytes, and renal collecting duct epithelium demonstrate positive staining for pre pro ANP. Staining is absent in Purkinje cells of $3 \mathrm{~d}$ lamb cerebellum (arrows). 

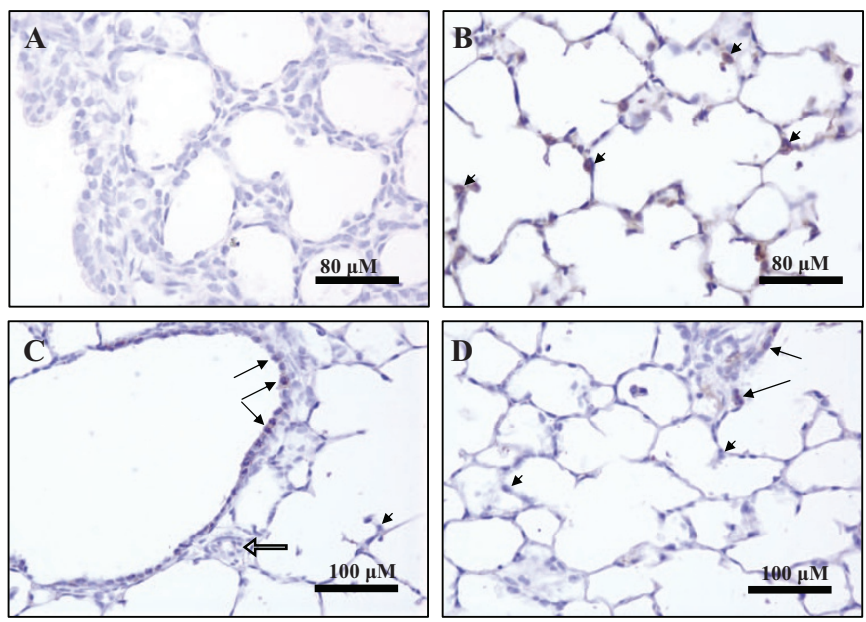

Figure 4. Immunostaining for ANP in fetal and newborn lamb lung. A, At $100 \mathrm{~d}$ gestation, staining for ANP is absent within all lung epithelial cells. $B$, Immunostaining for ANP in ATII cells from $136 \mathrm{~d}$ gestational age fetal lambs (arrowheads). $C$ and $D$, By $3 \mathrm{~d}$ and 4 wk of post gestation, ANP staining is absent in ATII cells (arrowheads) and is weakly positive in Clara cells (arrows). Open arrow shows an intraacinar artery.
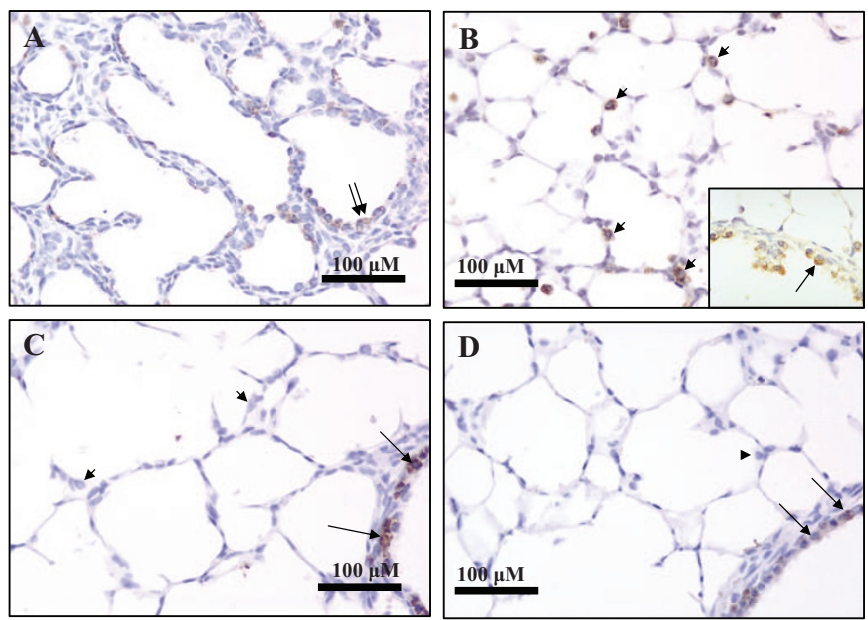

Figure 5. Immunostaining for NPR-A in fetal and newborn lamb lung. A, At $100 \mathrm{~d}$ gestation, weak staining for NPR-A is present in epithelial cells lining the developing airways (double arrows). $B$, Strong immunostaining for NPR-A is present in ATII cells (arrowheads) and Clara cells (inset-arrows) from $136 \mathrm{~d}$ gestational age fetal lambs. $C$, By $3 \mathrm{~d}$ post gestation, NPR-A staining is absent in ATII cells (arrowheads) but is still present in Clara cells (arrows). D, By 4 wk of age, NPR-A staining is absent in ATII cells (arrowheads) and is weak within Clara cells (arrows).

tial centrifugation of crude lung cell suspensions on a discontinuous Percoll gradient yielded a total cell number of $116 \pm$ $12.2 \times 10^{6}$ and an ATII cell yield of $45 \% \pm 8.5$ with a viability of $90.2 \% \pm 2.1$. Papanicolaou staining of cytospin preparations following differential sedimentation demonstrated a significant contamination by neutrophils and macrophages. Following panning of cells on $\operatorname{IgG}$ coated dishes, total cell numbers decreased significantly to $65 \times 10^{6} \pm 18.9$ (due to the removal of large numbers of WBC), ATII cell purity increased to $86.6 \% \pm 1.4$ and viability remained above $90 \%$. The combination of differential centrifugation on a Percoll gradient followed by panning on IgG coated dishes yielded the best combination of ATII cell number, purity, and viability.
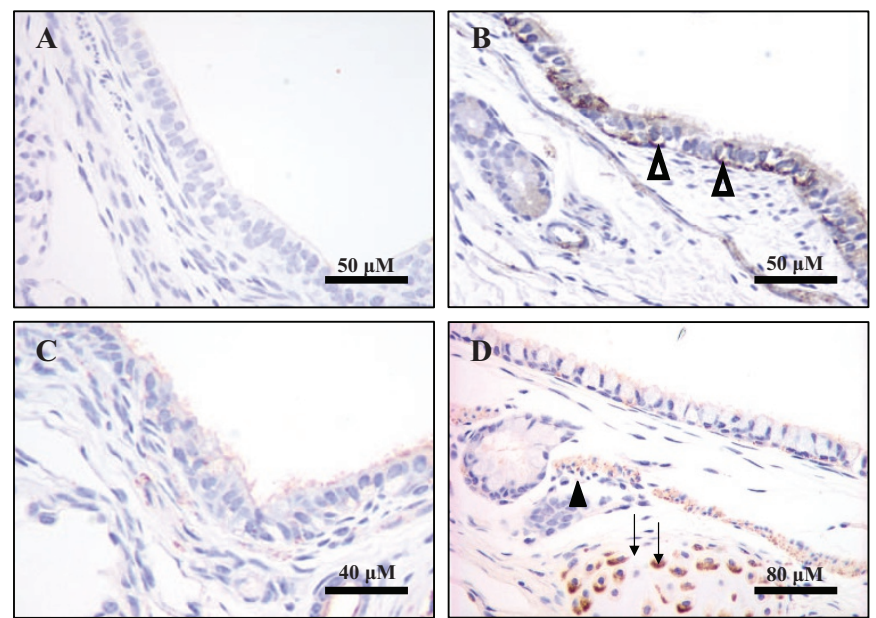

Figure 6. Immunostaining for NPR-A in fetal and newborn lamb bronchus. $A$, At $100 \mathrm{~d}$ gestation, staining for NPR-A is absent within ciliated epithelial lining the bronchus. $B$, At $136 \mathrm{~d}$ gestation, NPR-A staining is prominent at the basal surface of ciliated bronchial epithelial cells (open arrowheads). $C$ and $D$, Staining for NPR-A is absent in ciliated bronchial epithelial cells from $3 \mathrm{~d}$ and 4-wk-old lambs. Strong positive staining for NPR-A is present in chondrocytes (arrows) and bronchial smooth muscle (arrowhead).

Following overnight cell culture and washing of the plates, clusters of cells of a similar size and shape were attached to the culture plate. Tannic acid staining of cell cultures revealed large dark-brown intracellular inclusions consistent with surfactant-producing lamellar bodies.

$A N P$ stimulated release of ${ }^{3}[H]$ phosphatidylcholine $(P C)$ from ATII cells. The percent ${ }^{3}[\mathrm{H}] \mathrm{PC}$ release for untreated ATII cells was $2.33 \% \pm 0.5$ fetal $(n=4)$ and $1.73 \% \pm 0.19$ for newborn lambs $(n=4)$. Following a $3 \mathrm{~h}$ incubation with $10^{-4} \mathrm{M}$ terbutaline, the percent ${ }^{3}[\mathrm{H}] \mathrm{PC}$ release was $6.08 \% \pm$ 1.68 in fetal and $3.2 \% \pm 0.38$ in newborn lambs. ANP $10^{-10}$ $\mathrm{M}$ increased fetal and newborn ATII cell secretion of ${ }^{3}[\mathrm{H}] \mathrm{PC}$ $66 \%$ and $72 \%$ above baseline, respectively (Fig. $7 A, B$ ). In both near-term fetal and newborn ATII cells (Fig. 7), the addition of the PKG inhibitor PET significantly blocked $(>90 \%)$ the ability of ANP to stimulate ${ }^{3}[\mathrm{H}]$ PC release. The release of ${ }^{3}[\mathrm{H}]$ PC was unchanged by the addition of PET alone.

\section{DISCUSSION}

Previous studies have shown that the late-term fetus and newborn are exposed to elevated levels of circulating ANP and that the perinatal lung contains large numbers of binding sites for the NP $(10,27,28)$. Our findings indicate that distal lung epithelial cells (ATII and Clara cells) during late gestation contain relatively large amounts of ANP/prepro-ANP and express NPR-A within the apical region of the cell, suggesting an autocrine/paracrine mode of action for ANP released into the distal airspace. Supporting the role of the lung as a source of ANP synthesis is the presence of NP mRNA isolated from lung homogenates and the secretion of ANP from lung cells in culture $(29,30)$. Our finding of a rapid postnatal reduction in NPR-A is in contrast to earlier studies using lung slices that demonstrated a rise in pulmonary NPR-A activity postnatally (18). A possible explanation for this disparity is that many 


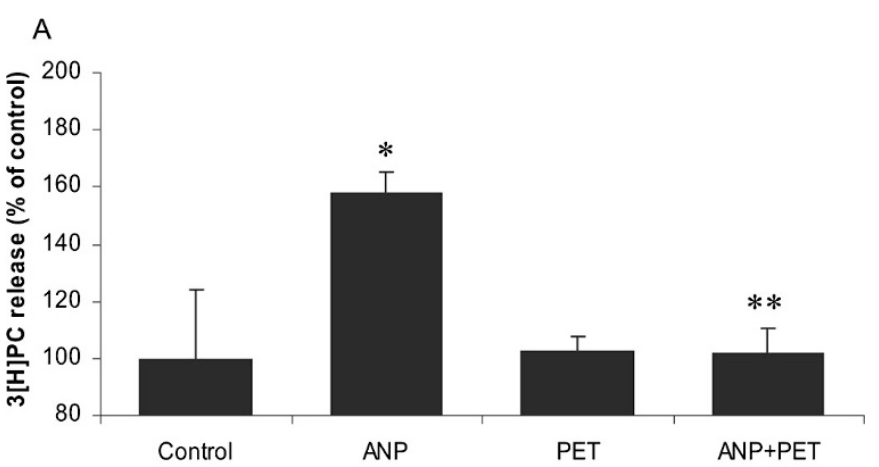

$$
\text { B }
$$

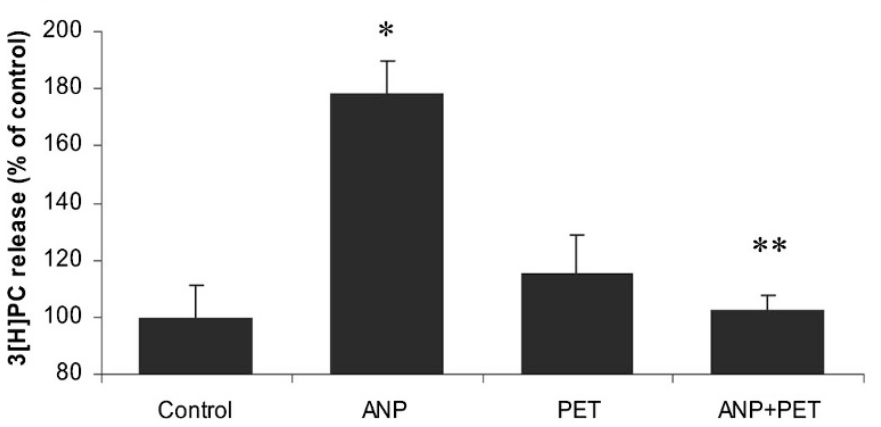

Figure 7. Effect of PKG blockade on ANP stimulated ${ }^{3}[\mathrm{H}]$ PC secretion from near-term fetal $(A)$ and newborn lambs $(B)$ ATII cells. ATII cells were plated and labeled overnight with ${ }^{3}[\mathrm{H}]$ choline chloride $(1 \mu \mathrm{ci} / \mathrm{mL})$ followed by a $3 \mathrm{~h}$ stimulation with ANP $\left(10^{-10} \mathrm{M}\right)$ with or without the PKG inhibitor PET $\left(10^{-5} \mathrm{M}\right)$. Values are the mean \pm SEM of four experiments in duplicate. ${ }^{*} p<$ 0.0001 from control; ** $p<0.0001$ from ANP alone.

nonepithelial cell types in the fetal and newborn lung also express NPR-A such as vascular smooth muscle, airway-associated smooth muscle, and chondrocytes. Unlike that seen in the distal lung epithelium, we did not observe a postnatal downregulation in nonepithelial cell populations. In fact, NPR-A staining increased significantly in chondrocytes following birth. Therefore, the increase in whole lung NPR-A activity may represent increases in NPR-A expression in nonepithelial cell populations.

Previous investigations in adult animals have implicated ANP as a possible hormonal regulator of surfactant release and water balance across the pulmonary epithelial barrier. Using an in vitro assay, we have demonstrated that ANP stimulates cGMPmediated release of PC from ATII cells isolated from both fetal and newborn lambs as coincubation of ANP with the specific PKG inhibitor PET resulted in an almost complete blockade of ANP-stimulated PC release. It has been well established that cAMP and activators of adenylyl cyclase such as beta agonists and ATP are potent stimulators of surfactant release $(31,32)$. However, studies examining the effect of cGMP on surfactant release have yielded mixed results. Initial studies of surfactant secretagogues demonstrated that the addition of cAMP but not cGMP resulted in a stimulation of PC secretion from cultured ATII cells (31). However, more recent reports demonstrate cGMP-mediated stimulation of PC release from both ATII cells in culture and in an isolated perfused lung system $(33,34)$ similar to our study. Currently, the physiologic level of ANP within the developing lung is not known. Although average basal plasma levels of ANP in the near-term fetal lamb have been shown to range from $130-165 \mathrm{pg} / \mathrm{mL}(10,35)$, this may not accurately reflect its concentration within the local environment at the level of the respiratory epithelial layer.

In the only other study that examined the effect of ANP on surfactant release (36), ANP at $\mu \mathrm{M}$ concentrations inhibited $\mathrm{PC}$ release from adult rat ATII cells. However, this inhibitory effect was seen only with respect to terbutaline-stimulated PC release. In the same report, ANP alone at pM concentrations did not inhibit or stimulate $\mathrm{PC}$ release. Because our study focused only on ATII cells isolated from fetal and 2 to 3-d-old newborn lambs this difference may be the effect of age or species differences. Finally, the effect of culture conditions in the present study must be considered. It has been recognized for some time that the culturing of adult ATII cells for even relatively brief periods of time leads to phenotypic alteration. This phenomenon may explain why in our investigation, newborn lung, which in situ expressed much less NP and NPR, demonstrated an equal response to our agonists in vitro.

In summary, prepro-ANP, ANP, and NPR-A appear in ATII cells late in gestation and decline sharply postnatally. ANP stimulates surfactant release in isolated ATII cells by a cGMPdependent mechanism, presumably through NPR-A activation. We speculate that the rise in ANP in late gestation may be priming the surfactant system, readying the lung for air breathing.

\section{REFERENCES}

1. Isohama Y, Rooney SA 2001 Glucocorticoid enhances the response of type II cells from newborn rats to surfactant secretagogues. Biochim Biophys Acta 1531:241250

2. Gonzales LW, Ballard PL, Ertsey R, Williams MC 1986 Glucocorticoids and thyroid hormones stimulate biochemical and morphological differentiation of human fetal lung in organ culture. J Clin Endocrinol Metab 62:678-691

3. Hitchcock KR 1980 Lung development and the pulmonary surfactant system: hormonal influences. Anat Rec 198:13-34

4. Tharaux PL, Dussaule JC, Couette S, Clerici C 1998 Evidence for functional ANP receptors in cultured alveolar type II cells. Am J Physiol 274:L244-L251

5. Kuhn M 2003 Structure, regulation, and function of mammalian membrane guanylyl cyclase receptors, with a focus on guanylyl cyclase-A. Circ Res 93:700-709

6. Potter LR, Abbey-Hosch S, Dickey DM 2006 Natriuretic peptides, their receptors, and cyclic guanosine monophosphate-dependent signaling functions. Endocr Rev 27:47-72

7. Tremblay J, Desjardins R, Hum D, Gutkowska J, Hamet P 2002 Biochemistry and physiology of the natriuretic peptide receptor guanylyl cyclases. Mol Cell Biochem 230:31-47

8. Cheung CY, Roberts VJ 1993 Developmental changes in atrial natriuretic factor content and localization of its messenger ribonucleic acid in ovine fetal heart. Am J Obstet Gynecol 169:1345-1351

9. Gardner DG, Wirtz H, Dobbs LG 1992 Stretch dependent regulation of atrial natriuretic peptide synthesis and secretion in cultured rat cardiomyocytes. Am J Physiol 263:E239-E244

10. Cheung CY 1995 Regulation of atrial natriuretic factor secretion and expression in the ovine fetus. Neurosci Biobehav Rev 19:159-164

11. Dagnino L, Drouin J, Nemer M 1991 Differential expression of natriuretic peptide genes in cardiac and extracardiac tissues. Mol Endocrinol 5:1292-1300

12. Gutkowska J, Tremblay J, Meyer R, Marcinkiewicz M, Nemer M 1991 Evidence for atrial natriuretic peptide (ANP) synthesis and the presence of ANP-transducing receptors in the rat olfactory bulb. J Neurochem 57:1855-1861

13. Crozier IG, Nicholls MG, Ikram H, Espiner EA, Yandle TG, Jans S 1986 Atrial natriuretic peptide in humans. Production and clearance by various tissues. Hypertension 8:II11-II15

14. Gutkowska J, Cantin M, Genest J, Sirois P 1987 Release of immunoreactive atrial natriuretic factor from the isolated perfused rat lung. FEBS Lett 214:17-20

15. Nakanishi K, Tajima F, Itoh H, Nakata Y, Hama N, Nakagawa O, Nakao K, Kawai T, Torikata C, Suga T, Takishima K, Aurues T, Ikeda T 1999 Expression of C-type natriuretic peptide during development of rat lung. Am J Physiol 277:L996-L1002

16. Lakshminrusimha S, D'Angelis CA, Russell JA, Nielsen LC, Gugino SF, Nickerson PA, Steinhorn RH 2001 C-type natriuretic peptide system in fetal ovine pulmonary vasculature. Am J Physiol Lung Cell Mol Physiol 281:L361-L368

17. Sirois P, Gutkowska J 1988 Atrial natriuretic factor immunoreactivity in human fetal lung tissue and perfusates. Hypertension 11:I62-I65

18. Muraki T, Irie K, Uchida Y, Nomoto T 1992 Developmental changes in the effect of atrial natriuretic peptide on tissue cyclic GMP content and particulate guanylate cyclase activity of aorta, kidney and lung of rats. Eur J Pharmacol 226:311-315 
19. Wedel BJ, Foster DC, Miller DE, Garbers DL 1997 A mutation of the atrial natriuretic peptide (guanylyl cyclase-A) receptor results in a constitutively hyperactive enzyme. Proc Natl Acad Sci USA 94:459-462

20. Gukovskaya AS, Gukovsky S, Pandol SJ, Gukovskaya AS, Gukovsky S, Pandol SJ 2000 Endoplasmic reticulum $\mathrm{Ca}(2+)$-ATPase inhibitors stimulate membrane guanylate cyclase in pancreatic acinar cells. Am J Physiol Cell Physiol 278:C363-C371

21. Fraenkel MB, Potocnik SJ, Wintour EM 1994 Atrial natriuretic peptide receptors are present and functional by midgestation in fetal sheep. Am J Physiol 267:F825-F830

22. Dobbs LG, Gonzales R, Williams MC 1986 An improved method for isolating type II cells in high yield and purity. Am Rev Respir Dis 134:141-145

23. Dobbs LG 1990 Isolation and culture of alveolar type II cells. Am J Physiol 258:L134-L147

24. Leslie CC, McCormick-Shannon K, Robinson PC, Mason RJ, Leslie CC, McCormickShannon K, Robinson PC, Mason RJ 1985 Stimulation of DNA synthesis in cultured rat alveolar type II cells. Exp Lung Res 8:53-66

25. Bligh EG, Dyer WJ 1959 A rapid method of total lipid extraction and purification. Can J Biochem Physiol 37:911-917

26. Kresch MJ, Lima DM, Lu H 1996 Developmental regulation of phospholipid secretion by fetal type II pneumocytes. Biochim Biophys Acta 1299:39-46

27. Mir TS, Laux R, Hellwege HH, Liedke B, Heinze C, von Buelow H, Laer S, Weil J 2003 Plasma concentrations of aminoterminal pro atrial natriuretic peptide and aminoterminal pro brain natriuretic peptide in healthy neonates: marked and rapid increase after birth. Pediatrics 112:896-899
28. Hersey RM, Nazir MA, Whitney KD, Klein RM, Sale RD, Hinton DA, Weisz J, Gattone VH II 1989 Atrial natriuretic peptide in heart and specific binding in organs from fetal and newborn rats. Cell Biochem Funct 7:35-41

29. Matsubara H, Mori Y, Umeda Y, Oikawa S, Nakazato H, Inada M 1988 Atrial natriuretic peptide gene expression and its secretion by pneumocytes derived from neonatal rat lungs. Biochem Biophys Res Commun 156:619-627

30. Carnio EC, Jankowski M, Mukaddam-Daher S, Gorska I, Antunes-Rodrigues J, Gutkowska J 1997 Elevated levels of natriuretic peptides in lungs of hamsters with genetic cardiomyopathy. Regul Pept 70:67-73

31. Mettler NR, Gray ME, Schuffman S, LeQuire VS 1981 beta-Adrenergic induced synthesis and secretion of phosphatidylcholine by isolated pulmonary alveolar type II cells. Lab Invest 45:575-586

32. Chander A, Fisher AB 1990 Regulation of lung surfactant secretion. Am J Physiol 258:L241-L253

33. Juvin P, Fournier T, Grandsaigne M, Desmonts JM, Aubier M 2002 Diesel particles increase phosphatidylcholine release through a NO pathway in alveolar type II cells. Am J Physiol Lung Cell Mol Physiol 282:L1075-L1081

34. Sun P, Wang J, Mehta PP, Beckman DL, Liu L 2003 Effect of nitric oxide on lung surfactant secretion. Exp Lung Res 29:303-314

35. Cheung CY, Miner LK, Brace RA 1989 Hyperosmolality elevates plasma atria natriuretic factor in the ovine fetus. Am J Physiol 257:E466-E472

36. Panchenko MP, Joyce-Brady M, Starikova MG, Oakes SM, Adachi R, Brody JS, Dickey BF 1998 Atrial natriuretic peptide modulates alveolar type 2 cell adenylyl and guanylyl cyclases and inhibits surfactant secretion. Biochim Biophys Acta 1403:115-125 